the scheme was quickly brought to a successful issue, so that new avenues of research work were opened to his numerous students. The relations between supraconductivity and magnetism both in elements and alloys were investigated, and such work is continuing under the able guidance of E. F. Burton, who succeeded McLennan on his retirement three years ago.

Prof. H. E. Armstrong wrote to The Times on October 12: "In McLennan we lost no mere scientific worker, but a man of the most admirable social gifts, indeed a man to fall in love with. It was a sight for the gods to see him beam with enthusiasm and joy, in his Royal Institution lecture, at his helium super-cooled ring in which the current put into it in Leyden in the afternoon continued to circulate. He had nursed it over from Holland by air."

In the Proceedings of the Royal Society, McLennan wrote more than fifty papers, in forty of which his research students collaborated. Perhaps it would not be invidious to name those who contributed two or more papers-D. S. Ainslie, H. J. C. Ireton, H. Grayson-Smith, A. B. McLay, A. R. MeLeod, G. M. Shrum. All this work, carried out at high pressure, sometimes led to stress and strain, and McLennan was always impatient with fools-sometimes with others-and though he could not suffer them gladly, his kindly, friendly nature usually restored sunshine after storm. He was a man who thought, spoke, wrote and lectured very clearly, and he was insistent on essential things. He was of a composite nature, greatly preferring friendship, but quite ready for a fight, and he fought hard. In the autumn of life his character was gentler and more mellow, and he was spared its winter. To his many friends and students he showed, time and again, the most thoughtful, unwearying kindness. A great factor in his life was the wise help and comfort of his able and interesting wife Elsie Monro, eldest daughter of William Ramsay, of Bowland, Scotland. Her death, two years ago, left him rather a desolate man, although he wore a brave face.

Of his work in England since his retirement Lord Rutherford writes of McLennan authoritatively : "Largely through his influence, the Union Minière of Brussels generously lent $5 \mathrm{gm}$. of radium to make a thorough investigation of the effects of mass radiation on cancerous growths. A committeo was formed to control this great experiment, presided over by the president of the Royal Society supported by the presidents of the Royal College of Physicians and Royal College of Surgeons, and representatives of the Medical Research Council and the Department of Scientific and Industrial Research. This work, which is still in progress, is being carried out at the Radium Institute. McLennan threw himself whole-heartedly into this new line of work, and personally supervised every detail of the scheme. He spent much of his time at the Institute, and characteristically established the friendliest relations not only with the staff but also with the patients under examination. His services to this investigation in radium beam therapy are indeed great, and his sudden removal is an irreparable loss. Warm-hearted and impulsive, his vitality, his boyish enthusiasm and transparent simplicity of nature, endeared him to all those who came closely into contact with him. His sudden end in the full tide of his activities is a great loss to science and humanity."

McLennan was born on April 14, 1867, and died of heart failure on his way from Paris to Calais on October 9, at the age of sixty-eight years. He received many and well-deserved honours. In 1924, he was president of the Royal Society of Canada and two years later was awarded the Flavelle Medal by that Society. He was elected a fellow of the Royal Society in 1915, and in the current year he received his knighthood.

A. S. EvE.

\section{Prof. Henry Briggs, O.B.E.}

Prof. Henry Brigas, who died in London on August 26 at the age of fifty-two years, had become, after a distinguished career, an authority on many subjects related to the scientific side of coal-mining. As head of the Department of Mining at Heriot-Watt College and Hood professor of mining at the University of Edinburgh, his influence amongst all students of mining technology was widely felt. In particular, mining engineers looked to Prof. Briggs for advice and information, based on his own original researches, on mine ventilation, on surveying and on the nature of coal. Latterly, he had interested himself in the subject of the production of oil from coal and carbonaceous materials, and had been appointed chairman of the Oil from Coal Committee of the Scottish National Development Council. He was a member of many scientific and technical societies, a member of council of the Institution of Mining Engineers and a fellow of the Royal Society of Edinburgh.

Briggs received his early education at Bradford whence, with a National Scholarship, he went to the Royal School of Mines and obtained the associateship with honours. He received his practical training in mining at collieries in Yorkshire, Cumberland and Wales and, previous to his appointment (in 1919) to the chair of mining at Heriot-Watt College, was, successively, demonstrator at the Royal School of Mines (and research assistant to Sir Clement le Neve Foster) and lecturer in mining at the University of Birmingham. His earlier research work included studies of mine rescue apparatus, and he was the inventor of an oxygen-breathing apparatus; during the War he carried out a number of investigations for the Trench Warfare Committee.

All Briggs's work showed originality of outlook and clarity of thought, and all his writings, with which he took particular pains, were lucid and literary. He had a keen and somewhat mordant wit which rendered his participation in discussions of controversial subjects highly effective; albeit he was constructive in his criticism. The coal-mining industry will feel his loss.
R. V. WHEELER. 